\title{
Perception of home science students towards RAWE and In-plant training programme
}

\author{
SUKHDEEP KAUR MANN* AND DIVYA SACHAN \\ Department of Extension Education and Communication Management, \\ Punjab Agricultural University, LUDHIANA(PUNJAB) INDIA
}

\begin{abstract}
The B.Sc. Home Science programme offers RAWE and In-plant training programme for B.Sc. last year students. The main objectives of RAWE programme are to provide an opportunity to B.Sc. Home Science (Hons.) students to develop the right perspective of rural life and develop positive attitude towards community. B.Sc. Home Science programme offers job oriented courses and In-plant training with the view that the internship in the related industry or institution is essential to provide practical training exposure to the students and also for the industries to be acquainted with the potentialities of B.Sc. Home Science graduates for mutual benefits. The present study was planned to find out the learning experiences, constraints and suggestions given by the B.Sc. Home Science graduates regarding RAWE and In-plant training programme. Study was conducted in College of Home Science, Punjab Agricultural University Ludhiana with 185 Home Science graduates and post graduates. Questionnaire technique was used for data collection. Findings of the study indicated that the major problem being faced by the students during In-plant training was short duration and during RAWE less amount of stipend and interaction with villagers regarding new technology. The suggestions put forth by the students were for increasing the duration of In-plant training, regular supervision and follow up by the teacher in -charge.
\end{abstract}

KEY WORDS : RAWE, In-plant training, Constraints, Suggestions

View Point Article : Mann, Sukhdeep Kaur and Sachan, Divya (2017). Perception of home science students towards RAWE and Inplant training programme. Internat. J. Home Sci. Extn. \& Comm. Manage., 4 (2): 77-81. DOI : 10.15740/HAS/IJHSECM/4.2/ 77-81.

Article History : Received : 22.04.2017; Revised : 14.06.2017; Accepted : 25.06.2017

\footnotetext{
* Author for correspondence
} 